\title{
Effect of water temperature and prey concentrations on initial development of Lophiosilurus alexandri Steindachner, 1876 (Siluriformes: Pseudopimelodidae), a freshwater fish
}

\author{
Rodrigo Takata ${ }^{1}$, Walisson de Souza e Silva ${ }^{2}$, Deliane Cristina Costa ${ }^{2}$, \\ Reinaldo Melillo Filho ${ }^{2}$ and Ronald Kennedy Luz ${ }^{2}$
}

The aim of this study was to investigate the effects of water temperature and prey concentrations (Artemia nauplii) on the initial development of Lophiosilurus alexandri larvae. The experiment was conducted using a 4 x 2 factorial design, with four water temperatures $\left(23,26,29\right.$ and $\left.32{ }^{\circ} \mathrm{C}\right)$, two different initial prey concentrations $\left(\mathrm{P}_{700}\right.$ and $\left.\mathrm{P}_{1,300}\right)$ and three replicates. Feeding was increased during the fifteen-day experiment. At the end of the experiment, the survival and condition factor were affected only by prey concentrations, with elevated numbers of Artemia nauplii leading to higher averages of these variables. The total length (TL) and specific growth rate were separately influenced by temperature and prey concentration, without interaction between them, and weight showed an interaction with these factors. In general, an increase of temperature $\left(23\right.$ to $32^{\circ} \mathrm{C}$ ) improved the growth and nitrogen gain in L alexandri larvae. For TL, the optimal temperatures estimated were 31.4 and $31.0{ }^{\circ} \mathrm{C}$ for $\mathrm{P}_{700}$ and $\mathrm{P}_{1,300}$, respectively. Similar mean body weight larvae and nitrogen gain were observed at $23{ }^{\circ} \mathrm{C}$ for both levels of prey concentrations. For other temperatures, the $\mathrm{P}_{1,300}$ level provided greater weight gain for L. alexandri. Therefore, it is suggested that temperatures between $29-32{ }^{\circ} \mathrm{C}$ combined with a higher level of prey concentration maximise the development and nitrogen gain in L. alexandri larvae. Moreover, this is the first result about nitrogen incorporation in neotropical fish larvae.

O objetivo deste estudo foi investigar os efeitos da temperatura da água e concentrações de presas (náuplios de Artemia) no desenvolvimento inicial de larvas de Lophiosilurus alexandri. O experimento foi conduzido em esquema fatorial $4 \mathrm{x}$ 2, com quatro temperaturas da água $\left(23,26,29\right.$ and $\left.32{ }^{\circ} \mathrm{C}\right)$, duas concentrações de presas $\left(\mathrm{P}_{700}\right.$ e $\left.\mathrm{P}_{1.300}\right)$ e três réplicas. A quantidade de alimento ofertado aumentou durante os 15 dias de experimento. Ao final do experimento a sobrevivência e o fator de condição foram afetados apenas pela concentração de presas, sendo que a maior concentração proporcionou médias superiores para as variáveis mencionadas. O comprimento total (CT) e a taxa de crescimento específico foram influenciados separadamente pelos fatores temperatura e concentração de presa, sem interação entre os fatores, e o peso individual das larvas apresentou interação entre os fatores estudados. Em geral, o aumento da temperatura (de 23 para $32{ }^{\circ} \mathrm{C}$ ) promoveu o crescimento e o ganho em nitrogênio nas larvas de $L$ alexandri. Para o CT, a temperatura ótima ficou em 31,4 e $31,0{ }^{\circ} \mathrm{C}$ para $\mathrm{P}_{700}$ e $\mathrm{P}_{1.300}$, respectivamente. Médias semelhantes do peso individual e ganho em nitrogênio foram observadas nos animais cultivados a $23{ }^{\circ} \mathrm{C}$ em ambos os níveis de concentração de presas. Nas demais temperaturas, o nível de $\mathrm{P}_{1.300}$ levou a um maior ganho em peso para as larvas de L. alexandri. Desta forma, conclui-se que o desenvolvimento inicial das larvas de L. alexandri é afetado por ambos os fatores estudados, e temperaturas entre $29-32{ }^{\circ} \mathrm{C}$ combinados ao maior nível de concentração de presas são as melhores opções para maximizar o desenvolvimento das larvas e o ganho em nitrogênio. Em adição, esse é o primeiro resultado sobre a incorporação de nitrogênio em larvas de peixes neotropicais.

Key words: Growth, Metabolism, Neotropical carnivorous fish, Pacamã, Physiology.

\section{Introduction}

Water temperature is one of the main abiotic factors that influence the ontogenetic development of fish (Kamler, 2008; Teletchea et al., 2009; Barron et al., 2012; Wen et al.,
2013). Temperature affects the growth (Johnston, 2006), survival (Keckeis et al., 2001; Hansen \& Falk-Petersen, 2002), metabolism (Conceição et al., 1998; Wen et al., 2013) and behaviour of fish species (Rijnsdorp et al., 2009). Furthermore, there is a range of temperatures in which fish

${ }^{1}$ Fundação Instituto de Pesca do Estado do Rio de Janeiro, Av. Presidente Vargas, 197 - Parque de Exposições - Colégio Agrícola Italo Milleno Lopes, 28540-000 Cordeiro, RJ, Brazil. rodrigo.takata@bol.com.br

${ }^{2}$ Laboratório de Aquacultura, Escola de Veterinária, Universidade Federal de Minas Gerais, 31270-901 Belo Horizonte, MG, Brazil. walissondsouza@gmail.com (WSS),delianecristinac@yahoo.com.br (DCC), reimelillo@yahoo.com.br (RMF), luzrk@yahoo.com (RKL) 
reach a maximum growth rate (Assis et al., 2004), feeding efficiency and nutrient utilisation (Person-Le Ruyet et al., 2004; Bogevik et al., 2010; Castro et al., 2012). Low water temperature may induce the reduction of food ingestion (Bendiksen et al., 2003), while high temperatures (heat stress) cause loss of nutrients through metabolic dysfunctions (Sun \& Chen, 2009; Bermudes et al., 2010). All mentioned situations can influence fish growth. However, information on the effects of temperature on neotropical fish larvae is still scarce.

Growth is initially linked to protein/nitrogen deposition and the increase in protein biomass and growth is an energetically expensive process (Conceição et al., 1997). The literature has shown that fish larvae increase body biomass every day, enhance weight and specific growth rate (SGR) in a few days (Dabrowski, 1984; Osse et al., 1997; Portella \& Dabrowski, 2008; Portella et al., 2012). Therefore, the understanding of adequate condition for nitrogen incorporation is essential for better nutrient assimilation and improves the knowledge about nitrogen metabolism in a neotropical fish larvae.

Larval development is closely associated to environmental conditions and food quality and availability. In this way, the relationship between temperature and food density (prey concentration) deserves special attention for condition factor, growth, survival, cannibalism, and feeding behaviour (Kestemont, 1995; Rabe \& Brown, 2000; Dou et al., 2003; Puvanendran et al., 2006; Georgalas et al., 2007; Santos \& Luz, 2009). Moreover, the understanding of such situations will contribute to the improvement of aquaculture systems, for example, the optimal amount of daily feed required in intensive larviculture. Previous studies showed that the neotropical fish larvae pacamã Lophiosilurus alexandri Steindachner, 1876 was raised at a temperature of $25-26{ }^{\circ} \mathrm{C}$, using Artemia nauplii as live food for the first 15 days of exogenous feeding (Luz et al., 2011). However, no information exists on the appropriate temperature for the maximum growth rate, nitrogen gain and survival rate for this species.

Lophiosilurus alexandri is an important stenohaline species inhabiting in the São Francisco River, Brazil. This fish presents good fillet quality without bones, and is also much appreciated by the fishing community. Rearing of $L$. alexandri has been developed mainly in response to declining wild stocks and, hence, the need to restore native populations. In this case, the species is reared in fish farms and for restocking program and juveniles with $1.5-3.0 \mathrm{~cm}$ of total length (TL) were used (Santos, personal communication).

Furthermore, L. alexandri have shown promising results for survival and growth during intensive larval rearing under laboratory conditions, indicating this species as a candidate for aquaculture (Luz \& Santos, 2008; Luz et al., 2011). This study aimed to improve the knowledge of L. alexandri's growth and nitrogen gain by more precisely evaluating the effect of different water temperatures and prey concentrations.

\section{Materials and methods}

Experimental conditions. Fertilised eggs of L. alexandri were collected in a $5.000 \mathrm{~L}$ tank with sand on the bottom with two males and three females (total weight ranging from 1.5 to $5.0 \mathrm{~kg}$ ) from a naturally spawning broodstock captured from nature and adapted to laboratory conditions at Federal University of Minas Gerais, Brazil (LAQUA). Fish reproduction occurred at $28^{\circ} \mathrm{C}$. Eggs and lecithotrophic larvae were incubated and reared, respectively, in rectangular aerated tanks at a temperature between 28 and $29^{\circ} \mathrm{C}$ (Souza et al., 2014). At the beginning of exogenous feeding, the larvae were quantified to initiate the period of rearing.

Larvae of $L$. alexandri at eight days post-hatching (mean length $11.9 \pm 0.7 \mathrm{~mm}$; mean weight $16.8 \pm 1.2$ $\mathrm{mg}$ ) were used to initiate the feeding trial. The entire experiment lasted 15 days. This period was adequate for production of fish with suitable size for a restocking program. Larvae were stocked at density of 30 larvae $\mathrm{L}^{-1}$ in 24 aquaria of $1.5 \mathrm{~L}$ (17 cm length, $13 \mathrm{~cm}$ width and $11 \mathrm{~cm}$ height). The photoperiod was 10L/14D and light intensity on the water surface was 150 lux (Digital Lux Meter, model: ITLD 260). The dissolved oxygen was checked every day and the concentration was greater than $5.0 \mathrm{mg} \mathrm{L}^{-1}$ throughout the experiment (Portable Waterproof Microprocessor Dissolved Oxygen Meter HI 9146, Hanna Instruments). Aeration was supplied by porous air stone without promoting water turbulence.

The experiment was conducted using a 4 × 2 factorial design, with four water temperatures $\left(23,26,29\right.$ and $\left.32^{\circ} \mathrm{C}\right)$, two daily prey concentrations, and three replicates each. In order to reach the predetermined temperatures in each treatment, the tanks were placed in thermostatic baths, and the temperature was gradually adjusted every two hours in $1^{\circ} \mathrm{C}$, over one day to corresponding treatments. The daily Artemia nauplii concentrations (P) were chosen as: $\mathrm{P}_{700}=$ 700 Artemia nauplii larvae ${ }^{-1} ; \mathrm{P}_{1,300}=1,300$ Artemia nauplii larvae ${ }^{-1}$ during the first five days of feeding. From the sixth to the $10^{\text {th }}$ day, these levels were increased to $\mathrm{P}_{700}=1,050$ Artemia nauplii larvae ${ }^{-1}, \mathrm{P}_{1,300}=1,950$ Artemia nauplii larvae ${ }^{-1}$. From the $11^{\text {th }}$ to the $15^{\text {th }}$ day, these levels were $\mathrm{P}_{700}=1,400$ Artemia_nauplii larvae ${ }^{-1} ; \mathrm{P}_{1,300}=2,600$ Artemia nauplii larvae ${ }^{-1}$. The larvae were fed three times a day at $9.00,13.00$ and 17.00 hours. To feeding the fish, the prey concentration was estimated and divided in equal amounts. This practice improves Artemia nauplii consumption by fish larvae. These prey concentrations were chosen based on previous studies for L. alexandri larvae (Pedreira et al., 2009). In order to feed the larvae, Artemia cysts were hatched daily. The nauplii were concentrated into a small volume of brackish water at $10 \%$ for quantification and subsequent larval feeding. This strategy was designed to avoid increasing the salinity of the water in the aquaria. Each day, before the first and the last feeding, the aquaria were siphoned to the waste removal. At that time, about 
$50 \%$ of the total water was renewed at the same temperature of the respective treatments.

Water quality measurements. The levels of total ammonia nitrogen (TAN) and $\mathrm{pH}$ were checked every three days according to APHA (2005) and Waterproof Tester (Hanna Instruments), respectively. Unionized ammonia $\left(\mathrm{NH}_{3}-\mathrm{N}\right)$ concentrations were calculated according to the equations of Ostrensky et al. (1992) using the $\mathrm{pH}$, temperature and salinity values measured during the experiment.

Biometric Indices. Samples of five animals per tank were randomly taken to perform measurements after 7 days of feeding. For this procedure, larvae were anaesthetised with eugenol $\left(80 \mathrm{mg} \mathrm{L}^{-1}\right)$. At the end of the experiment, all juveniles were used to obtain biometric indices, as described below, and the survival was also determined. The measurement of total length $(\mathrm{mm})$ was performed with an electronic Calliper (Starrett), and individual weight (mg) was measured using a precision balance (Marte, model: AY220 - $0.0001 \mathrm{~g}$ ). Growth parameters and condition factors were calculated as follows:

Specific growth rate $(\mathrm{SGR})=100 \times\left(\ln \mathrm{Wt}_{\mathrm{f}}-\ln \mathrm{Wt}_{\mathrm{i}}\right) /$ $\Delta \mathrm{t}$, considering $\Delta \mathrm{t}$ the time interval (in days) between $\mathrm{Wt}_{\mathrm{i}}$ (initial weight) and $\mathrm{Wt}_{\mathrm{f}}$ (final weight) measurements. Condition factor (K): (weight/length $)^{3} * 100$.

Analytical Procedure. Lophiosilurus alexandri larvae were sampled before starting and at the end of the trial, 100 larvae of the initial population and 20 larvae from each aquarium were induced to death by an overdose of eugenol $\left(200 \mathrm{mg} \mathrm{L}^{-1}\right)$. All fish were starved for $12 \mathrm{~h}$ before sampling. The samples were lyophilized to obtain the dry matter, and the total nitrogen was determined by a Leco auto-analyser. Nitrogen gain (NG) was calculated as follows: NG: (final larvae nitrogen content - initial larvae nitrogen content) / time (days).

Statistical Analysis. The survival rate and specific growth rate were arc-sin transformed for statistical analysis. Data were compared by factorial ANOVA, and means were compared using Student Newman Keuls (SNK) multiple range test, at $5 \%$ probability level using the SAEG program. The regressions analysis functions were used to estimate the optimum temperatures for length in $L$. alexandri, by calculating of the inflexion point from the first derivation of the regression. Equations of regression analysis were used to identify the appropriate temperature for the initial development of $L$. alexandri larvae.

\section{Results}

The $\mathrm{pH}$ was affected by temperature and prey concentration $(P<0.01)$ without exhibiting an interaction among them, with higher values at lower temperature and prey concentration $\left(\mathrm{P}_{700}\right)$. TAN was affected only by temperature $(P<0.01)$ and was reduced with increasing water temperature. For unionized ammonia, no differences were recorded for temperature, prey concentrations or an interaction among them $(P>0.05)$ (Table 1).

Table 1. Total ammonia nitrogen (TAN), $\mathrm{pH}$ and unionized ammonia nitrogen $\left(\mathrm{NH}_{3}-\mathrm{N}\right)$ during the larviculture of Lophiosilurus alexandri at different temperatures and prey concentrations. $\mathrm{F}$ values and means \pm standard deviation $(P<0.05)$. Means followed by the same letters on the columns did not differ by Tukey's test $(P<0.05)$. ${ }^{*} P<0.05$. ns - not significant. CV - coefficient of variation.

\begin{tabular}{|c|c|c|c|}
\hline \multirow[t]{2}{*}{ Statistical } & \multicolumn{3}{|c|}{ F values } \\
\hline & TAN (mg L-1) & $\mathrm{pH}$ & $\mathrm{NH}_{3}-\mathrm{N}^{1}$ \\
\hline Temperature $(\mathrm{T})$ & $84.15^{*}$ & $7.05^{*}$ & $0.13^{\mathrm{ns}}$ \\
\hline Prey concentrations $(\mathrm{P})$ & $2.01^{\mathrm{ns}}$ & $20.64 *$ & $0.03^{\mathrm{ns}}$ \\
\hline Interaction $\mathrm{T} \times \mathrm{P}$ & $2.20^{\mathrm{ns}}$ & $2.10^{\mathrm{ns}}$ & $0.27^{\mathrm{ns}}$ \\
\hline Temperatures & \multicolumn{3}{|c|}{ Means for temperature } \\
\hline $23^{\circ} \mathrm{C}$ & $0.038 \pm 0.007^{\mathrm{a}}$ & $8.79 \pm 0.02^{\mathrm{a}}$ & $0.0092 \pm 0.0016^{\mathrm{a}}$ \\
\hline $26^{\circ} \mathrm{C}$ & $0.011 \pm 0.005^{\mathrm{b}}$ & $8.75 \pm 0.05^{b}$ & $0.0032 \pm 0.0016^{\mathrm{a}}$ \\
\hline $29^{\circ} \mathrm{C}$ & $0.008 \pm 0.002^{\mathrm{bc}}$ & $8.72 \pm 0.02^{\mathrm{b}}$ & $0.0024 \pm 0.0008^{\mathrm{a}}$ \\
\hline \multirow[t]{2}{*}{$32{ }^{\circ} \mathrm{C}$} & $0.005 \pm 0.001^{\mathrm{c}}$ & $8.74 \pm 0.05^{\mathrm{b}}$ & $0.0020 \pm 0.0007^{\mathrm{a}}$ \\
\hline & \multicolumn{3}{|c|}{ Means for prey concentration } \\
\hline$P_{700}$ & $0.014 \pm 0.011^{\mathrm{a}}$ & $8.77 \pm 0.04^{\mathrm{a}}$ & $0.0040 \pm 0.0027^{\mathrm{a}}$ \\
\hline$P_{1,300}$ & $0.017 \pm 0.01^{\mathrm{a}}$ & $8.72 \pm 0.03^{b}$ & $0.0043 \pm 0.0037^{\mathrm{a}}$ \\
\hline CV (\%) & 25.54 & 29.79 & 85.03 \\
\hline
\end{tabular}

After seven days of feeding, weight was influenced only by temperature $(P<0.01)$ and prey concentration $(P<0.01)$ (Table 2). The highest weights were registered at $29 \mathrm{C}$ and $32{ }^{\circ} \mathrm{C}$ at $\mathrm{P}_{1,300}$. At this time, TL was affected only by the different temperatures $(P<0.01)$, and the highest were obtained at $29{ }^{\circ} \mathrm{C}$ and $32{ }^{\circ} \mathrm{C}$ and the lowest one at $23{ }^{\circ} \mathrm{C}$. After 15 days of exogenous feeding, TL was influenced by temperature $(P<0.01)$ and prey concentrations $(P<0.01)$, but also without interactions between these two factors $(P>0.05)$. The highest results of TL were found at $29^{\circ} \mathrm{C}$ and $32{ }^{\circ} \mathrm{C}$, at $\mathrm{P}_{1,300}$. The model of regression estimated the optimal temperature for TL of L. alexandri as $31.4^{\circ} \mathrm{C}$ and $31.0{ }^{\circ} \mathrm{C}$ for $\mathrm{P}_{700}$ and $\mathrm{P}_{1,300}$, respectively (Fig. 1). For weight, temperature $(P<0.01)$, prey concentrations $(P<0.01)$ and interactions between these factors $(P>0.01)$ (Table 2, Fig. 2) were registered. At a temperature of $23{ }^{\circ} \mathrm{C}$ both levels of prey concentrations provided similar weight gains for L. alexandri $(P>0.05)$. For the other temperatures, the $\mathrm{P}_{1,300}$ level provided the higher weights after 15 days of feeding. 
Table 2. Weight (mg), total length (TL) (mm), specific growth rate (SGR) $\left(\%\right.$ day $\left.^{-1}\right)$ after 7 and 15 days of exogenous feeding of Lophiosilurus alexandri. The Fulton's condition factor $(\mathrm{K})$ and survival (\%) were calculated at the end of the experiment. $\mathrm{F}$ values and means \pm standard deviation $(P<0.05)$. Means followed by the same letters on the columns did not differ by Tukey's test $(P<0.05)$. ${ }^{*} P<0.05$. ns - Not significant. CV - coefficient of variation.

\begin{tabular}{|c|c|c|c|c|c|c|c|c|}
\hline \multirow[t]{2}{*}{ Statistical } & \multicolumn{8}{|c|}{$\mathrm{F}$ values } \\
\hline & $\begin{array}{l}\text { Weight } \\
\text { (7 days) }\end{array}$ & $\begin{array}{c}\text { TL } \\
\text { (7 days) }\end{array}$ & $\begin{array}{l}\text { Weight } \\
\text { (15 days) }\end{array}$ & $\begin{array}{c}\text { TL } \\
\text { (15 days) }\end{array}$ & $\begin{array}{c}\text { SGR } \\
\text { (7 days) }\end{array}$ & $\begin{array}{c}\text { SGR } \\
\text { (15 days) }\end{array}$ & $\begin{array}{c}\mathrm{K} \\
\text { (15 days) }\end{array}$ & $\begin{array}{l}\text { Survival } \\
\text { (15 days) }\end{array}$ \\
\hline Temperature $(\mathrm{T})$ & $73.12^{*}$ & $97.20^{*}$ & $147.04 *$ & $61.36^{*}$ & $125.59 *$ & $0.69^{\text {ns }}$ & $2.76^{\mathrm{ns}}$ & $2.70^{\mathrm{ns}}$ \\
\hline Prey concentrations $(\mathrm{P})$ & $10.22 *$ & $3.10 \mathrm{~ns}$ & $106.33^{*}$ & $16.98^{*}$ & $16.03 *$ & $10.17^{*}$ & $13.54 *$ & $7.54 *$ \\
\hline Interaction $\mathrm{T} \times \mathrm{P}$ & $0.35^{\mathrm{ns}}$ & $0.01^{\mathrm{ns}}$ & $6.90^{*}$ & $1.22^{\mathrm{ns}}$ & $1.13^{\mathrm{ns}}$ & $2.66^{\mathrm{ns}}$ & $1.73^{\mathrm{ns}}$ & $1.47^{\mathrm{ns}}$ \\
\hline Temperatures & \multicolumn{8}{|c|}{ Means for temperature } \\
\hline $23{ }^{\circ} \mathrm{C}$ & $39.3 \pm 4.1^{\mathrm{c}}$ & $17.2 \pm 0.2^{\mathrm{c}}$ & $82.3 \pm 9.0$ & $21.9 \pm 0.8^{c}$ & $11.1 \pm 1.5^{\mathrm{c}}$ & $9.2 \pm 1.1$ & $0.0078 \pm 0.0008$ & $93.2 \pm 2.7$ \\
\hline $26^{\circ} \mathrm{C}$ & $63.3 \pm 7.2^{\mathrm{b}}$ & $20.0 \pm 0.7^{\mathrm{b}}$ & $130.7 \pm 17.5$ & $25.5 \pm 0.8^{\mathrm{b}}$ & $17.9 \pm 1.6^{\mathrm{b}}$ & $9.0 \pm 1.1$ & $0.0078 \pm 0.0005$ & $95.6 \pm 4.3$ \\
\hline $29^{\circ} \mathrm{C}$ & $82.9 \pm 8.8^{\mathrm{a}}$ & $22.2 \pm 0.5^{\mathrm{a}}$ & $162.5 \pm 26.7$ & $27.2 \pm 1.3^{\mathrm{a}}$ & $21.7 \pm 1.5^{\mathrm{a}}$ & $8.3 \pm 1.2$ & $0.0080 \pm 0.0004$ & $96.9 \pm 4.9$ \\
\hline $32{ }^{\circ} \mathrm{C}$ & $87.8 \pm 9.4^{\mathrm{a}}$ & $22.7 \pm 0.6^{\mathrm{a}}$ & $180.2 \pm 32.2$ & $27.7 \pm 1.1^{\mathrm{a}}$ & $22.5 \pm 1.5^{\mathrm{a}}$ & $8.8 \pm 2.1$ & $0.0081 \pm 0.0004$ & $90.7 \pm 9.3$ \\
\hline & \multicolumn{8}{|c|}{ Means for prey concentration } \\
\hline $\mathrm{P}_{700}$ & $64.2 \pm 20.5^{\mathrm{b}}$ & $20.3 \pm 2.3^{\mathrm{a}}$ & $120.6 \pm 31.5$ & $24.9 \pm 2.1^{\mathrm{b}}$ & $17.4 \pm 5.0^{\mathrm{b}}$ & $8.1 \pm 1.1^{\mathrm{b}}$ & $0.0076 \pm 0.0004^{b}$ & $91.9 \pm 6.2^{\mathrm{b}}$ \\
\hline $\mathrm{P}_{1,300}$ & $72.5 \pm 21.0^{\mathrm{a}}$ & $20.8 \pm 2.3^{\mathrm{a}}$ & $157.2 \pm 47.6$ & $26.3 \pm 2.7^{\mathrm{a}}$ & $19.2 \pm 4.6^{\mathrm{a}}$ & $9.6 \pm 1.2^{\mathrm{a}}$ & $0.0084 \pm 0.0006^{\mathrm{a}}$ & $96.3 \pm 4.9^{\mathrm{a}}$ \\
\hline CV (\%) & 9.22 & 3.02 & 6.24 & 3.18 & 3.54 & 6.74 & 6.28 & 7.9 \\
\hline
\end{tabular}
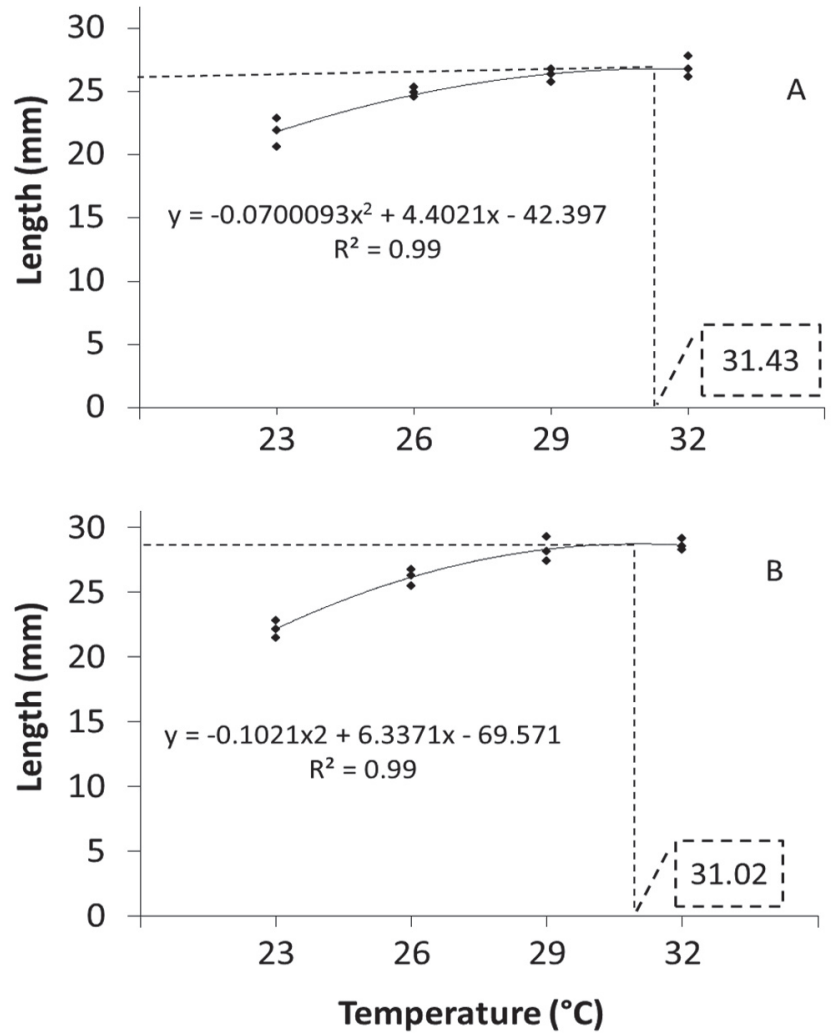

Fig. 1. Total length of Lophiosilurus alexandri after 15 days of exogenous feeding. The graph "A" and "B" showed the best temperature for the prey concentration $\mathrm{P}_{700}$ and $\mathrm{P}_{1,300}$, respectively.

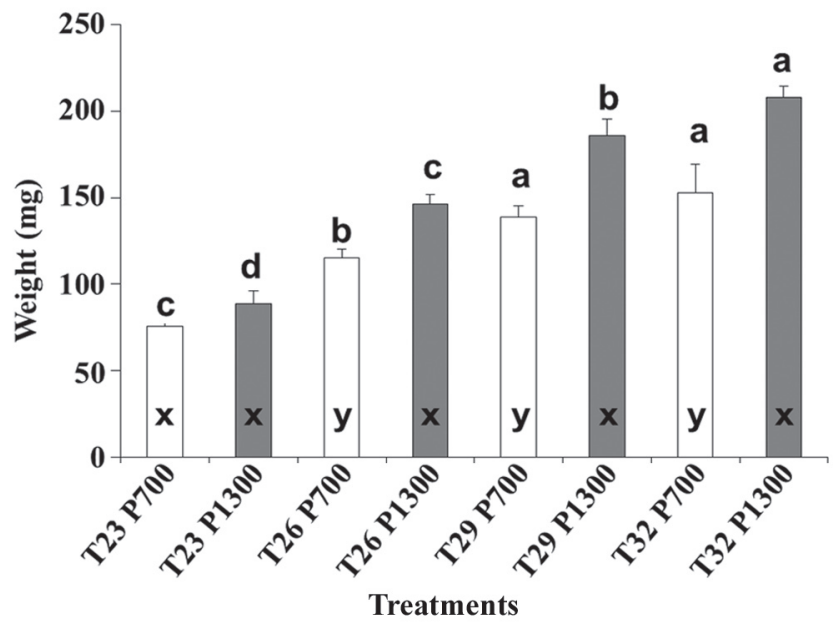

Fig. 2. Mean body weight of Lophiosilurus alexandri after 15 days of exogenous feeding. Different letters represent significant differences $(P<0.05)$ among temperatures $(\mathrm{a}, \mathrm{b}$, $\mathrm{c}$ and $\mathrm{d}$ ) and prey concentrations ( $\mathrm{x}$ and $\mathrm{y}$ ).

The SGR during the first seven days of feeding was affected by temperature $(P<0.01)$ and prey concentrations $(P<0.01)$, but again without an interaction between temperature and prey $(P>0.05)$ (Table 2). Higher SGRs were obtained with the prey concentrations of $\mathrm{P}_{1,300}$ at 29 and $32{ }^{\circ} \mathrm{C}$. Between the $8^{\text {th }}$ and $15^{\text {th }}$ day of exogenous feeding, SGR was modified only by the different prey concentrations $(P<0.01)$, and the $\mathrm{P}_{1,300}$ level provided the highest mean body weight. 
At the end of larviculture, survival and $\mathrm{K}$ were only modified by prey concentrations $(P<0.01)$, with the highest values for $\mathrm{P}_{1,300}$ (Table 2).

The $\mathrm{NG}^{1}$ showed an interaction $(P<0.01)$ between temperature and prey concentration. The increased temperature provided increase of NG in L. alexandri larvae (Table 3). The highest NG was found at $32{ }^{\circ} \mathrm{C}$. The prey concentration only had an effect at temperatures of 26 , 29 and $32{ }^{\circ} \mathrm{C}$, and the highest prey concentration showed superior $(P<0.01) \mathrm{NG}$. Larvae reared at $23{ }^{\circ} \mathrm{C}$ did not show statistical differences in NG when fed with different prey concentrations.

Table 3. Nitrogen gain $\left(\mathrm{mg} \mathrm{mg}^{-1} \mathrm{day}^{-1}\right)$ after 15 days of exogenous feeding of Lophiosilurus alexandri. $\mathrm{F}$ values and means \pm standard deviation $(P<0.05)$. Means followed by the same letters $(\mathrm{a}, \mathrm{b}$, on the columns and A, B, C, D on the lines) did not differ by Tukey's test $(P<0.05)$. ${ }^{*} P<0.05$.

\begin{tabular}{|c|c|c|c|c|c|}
\hline \multicolumn{6}{|c|}{ Statistical } \\
\hline F values & $\begin{array}{c}\text { Temperature } \\
\text { (T) }\end{array}$ & \multicolumn{2}{|c|}{$\begin{array}{l}\text { Prey concentration } \\
\text { (P) }\end{array}$} & \multicolumn{2}{|l|}{$\begin{array}{c}\text { Interaction } \\
\text { T x P }\end{array}$} \\
\hline Nitrogen gain & $347.35^{*}$ & \multicolumn{2}{|c|}{$233.24 *$} & $15.71^{*}$ & \\
\hline \multicolumn{6}{|c|}{ Temperature $\left({ }^{\circ} \mathrm{C}\right)$} \\
\hline $\begin{array}{c}\text { Prey } \\
\text { concentrations }\end{array}$ & 23 & 26 & 29 & 32 & Average \\
\hline $\mathrm{P}_{700}$ & $37.6 \pm 0.5^{\mathrm{Da}}$ & $62.3 \pm 1.0^{\mathrm{Cb}}$ & $78.1 \pm 1.9^{\mathrm{Bb}}$ & $90.0 \pm 5.7^{\mathrm{Ab}}$ & $67.0 \pm 20.6$ \\
\hline$P_{1,300}$ & $45.1 \pm 0.6^{\mathrm{Da}}$ & $83.9 \pm 1.2^{\mathrm{Ca}}$ & $107.4 \pm 2.9^{\mathrm{Ba}}$ & $125.8 \pm 8.0^{\mathrm{Aa}}$ & $90.5 \pm 31.7$ \\
\hline Average & $41.3 \pm 4.1$ & $73.1 \pm 11.8$ & $92.7 \pm 16.2$ & $107.9 \pm 20.6$ & \\
\hline
\end{tabular}

\section{Discussion}

Temperature is a critical factor that influences fish during the development of the embryos and larvae (Baras et al., 2011; Barron et al., 2012). This variable and prey concentrations were key factors during the early development of the carnivorous larvae of $L$. alexandri. The different temperatures $\left(23\right.$ to $\left.32{ }^{\circ} \mathrm{C}\right)$ tested did not affect survival, but the highest prey concentration provided higher survival. In contrast, temperatures between 23 and $33{ }^{\circ} \mathrm{C}$ affected the survival of other tropical fish larvae, the Asian catfish Pangasianodon hypophthalmus, for which temperature of $23{ }^{\circ} \mathrm{C}$ was found to be lethal for the species at the beginning of development (Baras et al., 2011). Furthermore, it is important to note that, in the present study, both conditions of temperature and prey concentration showed high survivals ( $>90 \%)$.

Larvae of $L$. alexandri reared at $23{ }^{\circ} \mathrm{C}$ showed similar weight and nitrogen gain, regardless of the prey concentrations, which indicate that the low temperature limits food intake and/or nitrogen gain, possibly induced by disturbances of the larvae metabolism. Meekan et al. (2003) showed that water temperature explained approximately $30 \%$ of the variation in growth of tropical reef fish larvae Pomacentrus coelestis while chlorophyll and zooplankton abundance explained 4.1 and 3.5\%, respectively. Similar to our study, at low temperature, the concentration of prey did not affect the growth of tropical fish larvae.

The consequence of $L$. alexandri larvae reared without thermal comfort could explain the highest TANs and $\mathrm{pHs}$ found during larviculture at $23{ }^{\circ} \mathrm{C}$. In such cases, lower food consumption (Fletcher, 1984) could enhance Artemia nauplii degradation, and the metabolic disorder generated by low food intake could induce an increase of energy loss in the process of nitrogen excretion, as has been observed for barramundi Lates calcarifer juveniles, when reared in extreme temperatures of 23.3 and $37.9{ }^{\circ} \mathrm{C}$ (Bermudes et al., 2010).

From the point of view of production, at low temperatures is recommended to use low concentrations of prey to reduce the cost of live food and to prevent the degradation of water quality. On the other hand, larvae fed on high concentrations of prey $\left(\mathrm{P}_{1,300}\right)$ at 29 and $32{ }^{\circ} \mathrm{C}$ showed higher growth and nitrogen gain than those fed with low prey concentrations. This fact indicates a possible increase in food consumption and more efficient use of food as an energy and nitrogen sources. Similar to these results, larvae of the African catfish Clarias gariepinus reared at a high temperature $\left(31^{\circ} \mathrm{C}\right)$ showed an increase in rates of absorption and depletion of amino acids, as well as a greater efficiency in the use of yolk nutrients (Conceição et al., 1998). Wen et al. (2013) evaluated the development and the dynamics of metabolic substrates (carbohydrate, protein, lipid and fatty acids) during the embryonic and yolk-sac larval stages of the devil stinger, Inimicus japonicus and found that high temperatures provided depletion of protein in the embryo stage.

Extreme temperatures and greater concentrations of prey than those used in this study should be investigated in the future, in order to determine the lethal temperature, the metabolic demand in thermal stress and the efficiency in the nutrient utilization by netropical fish larvae, more precisely determining the best relation among nutrient utilization and temperature. Moreover, assessing the dynamics of metabolic substrates for neotropical fish larvae, this information will help to understand some physiological effects induced by high temperatures found in tropical areas.

In the present study, the temperatures of 29 and $32{ }^{\circ} \mathrm{C}$ provided the highest growth rate for $L$. alexandri at both levels of prey concentrations, and the best temperatures for TL were estimated to be 31.4 and $31.0{ }^{\circ} \mathrm{C}$ for $\mathrm{P}_{700}$ and $\mathrm{P}_{1,300}$, respectively. For $L$. alexandri, it is interesting to note that although there were differences in TL with $\mathrm{P}_{700}$ and $\mathrm{P}_{1,300}$, both levels provided similar values for the optimal temperature, approximately $31{ }^{\circ} \mathrm{C}$. In other words, the energy source provided by lower level of prey concentration was adequate, to at least maintain the energetic requirements of the metabolism, and only caused an effect on the growth rate. 
The amount of food available is an essential aspect to larval growth. As at in the present study, Santos \& Luz (2009) showed that the SGR of three neotropical fish larvae "surubim" Pseudoplatystoma corruscans, "curimbata" Prochilodus costatus and L. alexandri were higher using increased prey concentrations (Artemia nauplii) during the first days of feeding.

Condition factor $(\mathrm{K})$ did not have any relationship to temperature tested in this study. However, the highest level of food provided a superior $\mathrm{K}$ for $L$. alexandri, indicating the most appropriate concentration of food is $P_{1,300}$. These results are supported by Barron et al. (2012), in which larvae and juvenile of the North American burbot Lota lota maculosa did not show alterations of $\mathrm{K}$ when reared at different temperatures $\left(10,15\right.$ and $\left.20^{\circ} \mathrm{C}\right)$ with the same feeding protocol.

Information about the effect of temperature and food amount is known for marine fish larvae (Meekan et al., 2003; Donelson et al., 2011); however, information for rearing of larvae of neotropical freshwater fish species are still scarce. The present study is not only useful for developing a better understanding of temperatures and the food amount necessary for the growth and nitrogen gain of $L$. alexandri larvae, but it is also important for investigations concerning water temperature and live food variations in tropical areas. Thus, our results will contribute to understand the effect of temperature and live food concentration in the larviculture of neotropical freshwater fish and, consequently, a more sustainable fish production industry. In the future, these results will also contribute to the standardisation of larviculture techniques for this species in aquaculture and stocking programs.

Water temperature and the prey concentration are key factors for initial growth and nitrogen gain of $L$. alexandri larvae and temperatures between $29-32{ }^{\circ} \mathrm{C}$ and prey concentrations ranging from 1,300 to 2,600 nauplii larvae $e^{-1}$ during the first fifteen days of exogenous feeding are recommended for larvae of this species.

\section{Acknowledgements}

We would like to acknowledge FAPEMIG, MCT/ CNPq/CT-Agronegócio/MPA (25/2010), CAPES-REUNI for the implementation of scientific grants and for their financial support.

\section{Literature cited}

American Public Health Association, APHA. 2005. Standard methods for the examination of water and wastewater. $21^{\text {th }}$ ed. Washington: APHA; AWWA; WEF.

Assis, J. M. F., R. F. Carvalho, L. Barbosa, C. A. Agostinho \& M. Dal Pai-Silva. 2004. Effects of incubation temperature on muscle morphology and growth in the pacu (Piaractus mesopotamicus). Aquaculture, 237: 251-267.

Baras, E., T. Raynaud, J. Slembrouck, D. Caruso, C. Cochet \& M. Legendre. 2011. Interactions between temperature and size on the growth, size heterogeneity, mortality and cannibalism in cultured larvae and juveniles of the Asian catfish, Pangasianodon hypophthalmus (Sauvage). Aquaculture Research, 42: 260-276.

Barron, J. M., R. Nathan, P. J. Anders, J. A. Egan, S. C. Ireland \& K. D. Cain. 2012. Effects of temperature on the intensive culture performance of larval and juvenile North American Burbot (Lota lota maculosa). Aquaculture, 364-365: 67-73.

Bendiksen, E. Å., O. K. Berg, M. Jobling, A. M. Arnesen \& K. Måsøval. 2003. Digestibility, growth and nutrient utilization of Atlantic salmon parr (Salmo salar L.) in relation to temperature, feed fat content and oil source. Aquaculture, 224: 283-299.

Bermudes, M., B. Glencross, K. Austen \& W. Hawkins. 2010. The effects of temperature and size on the growth, energy budget and waste outputs of barramundi (Lates calcarifer). Aquaculture, 306: 160-166.

Bogevik, A. S., R. J. Henderson, H. Mundheim, R. Waagbø, D. R. Tocher \& R. E. Olsen. 2010. The influence of temperature on the apparent lipid digestibility in Atlantic salmon (Salmo salar) fed Calanus finmarchicus oil at two dietary levels. Aquaculture, 309: 143-151.

Castro, C., A. Pérez-Jiménez, I. Guerreiro, H. Peres, M. CastroCunha \& A. Oliva-Teles. 2012. Effects of temperature and dietary protein level on hepatic oxidative status of Senegalese sole juveniles (Solea senegalensis). Comparative Biochemistry and Physiology Part A, 163: 372-378.

Conceição, L. E., R. O. A. Ozório, E. A. Suurd \& J. A. J. Verreth. 1998. Amino acid profiles and amino acid utilization in larval African catfish (Clarias gariepinus): effects of ontogeny and temperature. Fish Physiology and Biochemistry, 19:43-57.

Conceição, L. E., T. van der Meeren, J. A. J. Verreth, M. S. Evjen, D. F. Houlihan \& H. J. Fyhn. 1997. Amino acid metabolism and protein turnover in larval turbot (Scophthalmus maximus) fed natural zooplankton or Artemia. Marine Biology, 129: 255-265.

Dabrowski, K. 1984. The feeding of fish larvae: present "state of the art" and perspectives. Reproduction Nutrition Development, 6: 807-833.

Donelson, J. M., P. L. Munday, M. I. McCormick \& G. E. Nilsson. 2011. Acclimation to predicted ocean warming through developmental plasticity in a tropical reef fish. Global Change Biology, 17: 1712-1719.

Dou, S., R. Masuda, M. Tanaka \& K. Tsukamoto. 2003. Identification of factors affecting the growth and survival of the settling Japanese flounder larvae, Paralichthys olivaceus. Aquaculture, 218: 309-327.

Fletcher, D. J. 1984. The physiological control of appetite in fish. Comparative Biochemistry and Physiology, 78a: 617-628.

Georgalas, V., S. Malavasi, P. Franzoi \& P. Torricelli. 2007. Swimming activity and feeding behaviour of larval European sea bass (Dicentrarchus labrax L.): Effects of ontogeny and increasing food density. Aquaculture, 264: 418-427.

Hansen, T. K. \& I-B. Falk-Petersen. 2001. Growth and survival of first-feeding spotted wolffish (Anarhichas minor Olafsen) at various temperature regimes. Aquaculture Research, 33: 1119-1127.

Johnston, I. A. 2006. Environment and plasticity of myogenesis in teleost fish. The Journal of Experimental Biology, 209: 2249-2264. 
Kamler, E. 2008. Resource allocation in yolk-feeding. Reviews in Fish biology and Fisheries, 18: 143-200.

Keckeis, H., E. Kamler, E. Bauer-Nemeschkal \& K. Schneeweiss. 2001. Survival, development and food energy partitioning of nase larvae and early juveniles at different temperatures. Journal of Fish Biology, 59: 45-61.

Kestemont, P. 1995. Influence of feed supply, temperature and body size on growth of goldfish Carassius auratus larvae. Aquaculture, 136: 341-349.

Luz, R. K. \& J. C. E. Santos. 2008. Densidade de estocagem e salinidade da água na larvicultura do pacamã. Pesquisa Agropecuária Brasileira, 43: 903-909.

Luz, R. K., J. C. E. Santos, M. M. Pedreira \& E. A. Teixeira. 2011. Effect of water flow rate and feed training on "pacamã" (Siluriforme: Pseudopimelodidae) juvenile production. Arquivo Brasileiro de Medicina Vetarinária e Zootecnia, 63: 973-979.

Meekan, M. G., J. H. Carleton, A. D. McKinnon, K. Flynn \& M. Furnas. 2003. What determines the growth of tropical reef fish larvae in the plankton: food or temperature? Marine Ecology Progress Series, 256: 193-204.

Osse, J. W. M., J. G. M. van den Boogaard, G. M. J. van Snik \& L. van der Sluys. 1997. Priorities during early growth of fish larvae. Aquaculture, 155: 249-258.

Ostrensky, A., M. A. Marchiori \& L. H. Poersch. 1992. Toxicidade aguda da amônia no processo produtivo de póslarvas de Penaeus paulensis Pérez-Farfante, 1967. Anais Academia Brasileira de Ciências, 64: 383-389.

Pedreira, M. M., R. K. Luz, J. C. E. Santos, E. V. Sampaio \& R. S. F. Silva. 2009. Biofiltração da água e tipos de substrato na larvicultura do pacamã. Pesquisa Agropecuária Brasileira, 44: 511-518.

Person-Le Ruyet, J., K. Mahé, N. Le Bayon \& H. Le Delliou. 2004. Effects of temperature on growth and metabolism in a Mediterranean population of European sea bass, Dicentrarchus labrax. Aquaculture, 237: 269-280.

Portella, M. C. \& K. Dabrowski. 2008. Diets, physiology, biochemistry and digestive tract development of freshwater fish larvae. Pp. 227-279. In: Cyrino, J. E. P., D. P. Bureau \& B. G. Kapoor (Eds.). Feeding and digestive functions of fishes. USA, Science Publishers.
Portella, M. C., N. J. Leitão, R. Takata \& T. Lopes. 2012. Alimentação e Nutrição de Larvas. Pp. 185-216. In: Fracalossi, D. M. \& J. E. P. Cyrino (Eds.). Nutriaqua: nutrição e alimentação de espécies de interesse para a aquicultura brasileira. Florianópolis, Sociedade Brasileira de Aquicultura e Biologia Aquática.

Puvanendran, V., A. L. Burt \& J. A. Brown. 2006. Can Atlantic cod (Gadus morhua) larvae be weaned faster onto dry feed at higher temperatures? Aquaculture, 255: 334-340.

Rabe, J. \& J. A. Brown. 2000. A pulse feeding strategy for rearing larval fish: an experiment with yellowtail flounder. Aquaculture, 191: 289-302.

Rijnsdorp, A. D., M. A. Peck, G. H. Engelhard, C. Möllmann \& J. K. Pinnegar. 2009. Resolving the effect of climate change on fish populations. ICES Journal of Marine Science, 66: 1570-1583.

Santos, J. C. E. \& R. K. Luz. 2009. Effect of salinity and prey concentrations on Pseudoplatystoma corruscans, Prochilodus costatus and Lophiosilurus alexandri larviculture. Aquaculture, 287: 324-328.

Souza, M. G., M. M. Costa, A. G. L. Seabra, R. E. Balen \& F. Meurer. 2014. Alimento vivo e inerte para alevinos de pacamã. Revista Agrarian, 7: 360-364.

Sun, L. \& H. Chen. 2009. Effects of ration and temperature on growth, fecal production, nitrogenous excretion and energy budget of juvenile cobia (Rachycentron canadum). Aquaculture, 292: 197-206.

Teletchea, F., J-N. Gardeur, E. Kamler \& P. Fontaine. 2009. The relationship of oocyte diameter and incubation temperature to incubation time in temperate freshwater fish species. Journal of Fish Biology, 74: 652-668.

Wen, W., X. Huang, Q. Chen, L. Feng \& L. Wei. 2013. Temperature effects on early development and biochemical dynamics of a marine fish, Inimicus japonicus. Journal of Experimental Marine Biology and Ecology, 442: 22-29.

Submitted November 18, 2013 Accepted September 13, 2014 by Bernardo Baldisserotto Published December 27, 2014 
